\title{
Is it cheating or learning the craft of writing? Using Turnitin to help students avoid plagiarism
}

\author{
Lynne Graham-Matheson ${ }^{\mathrm{a} *}$ and Simon Starr $^{\mathrm{b}}$ \\ ${ }^{a}$ Education Research Directorate, Faculty of Education, Canterbury Christ Church University, \\ Canterbury, UK; ${ }^{b}$ Faculty Learning Technologist, Learning and Teaching Enhancement Unit, \\ Canterbury Christ Church University, Canterbury, UK
}

(Received 15 January 2012; final version recieved 6 March 2013)

\begin{abstract}
Plagiarism is a growing problem for universities, many of which are turning to software detection for help in detecting and dealing with it. This paper explores issues around plagiarism and reports on a study of the use of Turnitin in a new university. The purpose of the study was to inform the senior management team about the plagiarism policy and the use of Turnitin. The study found that staff and students largely understood the university's policy and Turnitin's place within it, and were very supportive of the use of Turnitin in originality checking. Students who had not used Turnitin were generally keen to do so. The recommendation to the senior management team, which was implemented, was that the use of Turnitin for originality checking should be made compulsory where possible - at the time of the study the use of Turnitin was at the discretion of programme directors. A further aim of the study was to contribute to the sector's body of knowledge. Prevention of plagiarism through education is a theme identified by Badge and Scott (2009) who conclude an area lacking in research is "investigation of the impact of these tools on staff teaching practices". Although a number of recent studies have considered educational use of Turnitin they focus on individual programmes or subject areas rather than institutions as a whole and the relationship with policy.
\end{abstract}

Keywords: higher education; plagiarism; assessment; Turnitin

\section{Introduction}

Canterbury Christ Church University is a new university, originally established in 1962 as a teacher training college. It is the largest provider of programmes for the public services (notably education, health and social care and policing) in Kent and has around 18,000 students, many of them part-time and mature students, across five campuses. A total of 1,500 students are from overseas, around a third of these from outside the EU.

The aim of the study was to develop the University's policy and practice through establishing staff and student understanding of the plagiarism policy and how Turnitin relates to it, strategies for using Turnitin and the role of Turnitin in education to avoid plagiarism.

*Corresponding author. Email: lynne.graham-matheson@canterbury.ac.uk 


\section{Graham-Matheson and S. Starr}

A further aim was to contribute to the sector's body of knowledge. In 2009 Badge and Scott concluded that in relation to plagiarism detection an area lacking in research is "investigation of the impact of these tools on staff teaching practices". Although a number of recent studies have considered the educational use of Turnitin (Davis and Carroll 2009; Flynn 2010; McCarthy and Rogerson 2009; Wiggins 2010), they focus on individual programmes or subject areas rather than institutions as a whole and the relationship with policy. Our understanding was that at the time this study was undertaken (2010/11), this was the first institution-wide study of the use of Turnitin.

\section{Review of literature}

\section{The problem of plagiarism}

Plagiarism is a growing problem for universities. A Daily Telegraph headline (Barrett 2011) highlighted "the cheating epidemic at Britain's universities" with "thousands of students caught plagiarising, trying to bribe lecturers and buying essays from the Internet." Higher education institutions (HEIs) have met concerns over the increasing problem of plagiarism with a range of measures, particularly electronic detection systems. The UK national licence for Turnitin was only introduced in 2002/ 3 but by 2009 the software was used by over 95\% of HEIs [Barrie 2008 cited in Badge and Scott (2009)] and is now used worldwide by over 10,000 institutions in 126 countries (iParadigms 2012). SafeAssign, launched by Blackboard in 2007, processed one million papers in its first year (Blackboard 2008). None of the systems available actually detect plagiarism, they merely detect and flag up non-original text (text that matches to another source), which may well be legitimate, e.g. correctly cited direct quotations.

Detecting non-original text is one issue but defining plagiarism is another. As de Jager and Brown (2010) point out, plagiarism is complex and can involve a number of different behaviours, ranging from deliberate dishonesty or negligence to ignorance of what plagiarism is or an inability to deal with it. In the West, plagiarism is usually defined as taking someone else's work and passing it off as your own: in an academic context plagiarism is regarded as dishonesty or cheating, and penalties can be severe. Definitions of plagiarism have varied over time and differ between cultures. Historically painters and others were encouraged to copy the works of the masters it was even thought presumptuous for writers to invent their own plots - and in some cultures it is still seen as a mark of respect to incorporate someone else's work into your own (Hayes and Introna 2005, p. 215).

On the question of detection, Woessner (2004) says that unless the penalties and consequences of plagiarism are made clear to students, detecting plagiarism will offer no deterrent but there is a growing view that not all incidences of plagiarism are the same, and treating them all as academic misconduct may not be appropriate as some students struggle to acquire the skills of academic writing. English as a foreign language and science students often use the "mosaic technique" (Ashworth, Bannister, and Thorne 1997, p. 201) or "patchwriting" (Howard 1999) (weaving together a paper from different sources, properly referenced, but where the writer's input is merely to thread the material together) to learn the academic writing style of their discipline through imitation (Eckel 2010). This may not be deliberately deceptive (Howard 1999; Pecorari 2003) and may be regarded as acceptable by 
students who can be confused by what teachers actually mean by plagiarism (Ashworth, Bannister, and Thorne 1997).

Plagiarism has become more of an issue in recent years (Larkham and Manns 2002, and others), partly through the increase in university student numbers, often without a corresponding increase in resources, but mainly through the growth of the Internet with the easy availability of essays for purchase and other ways in which students can "cheat". ". . . after Google's launch in 1998 the Internet became a public elixir of information of increasingly dubious origin, seemingly meeting steadily rising student demand" (Mainka, Raeburn, and Earl 2006, p. 13). The availability of information on the Internet also makes it more difficult for academics to identify plagiarism, which was easier when students tended to access just a few significant texts that were well known to staff.

\section{Dealing with plagiarism}

There is no common view of how plagiarism should be handled and as McGowan (2005) points out "One of the consequences of stating or implying that "all" plagiarism is "unacceptable" is that the default situation is necessarily a disciplinary rather than an educational one" (p. 3). Procedures and penalties related to plagiarism vary significantly across UK HEIs - Carroll (2007) makes the point that not all institutions have policies and strategies in place to deal with it. In their survey, Tennant, Rowell, and Duggan (2007) found a large minority of HEIs using policies that give only limited guidance regarding penalties to be applied but if individual teachers can interpret the policy and respond in different ways "it puts students in a perilous situation, and undermines the efforts of the university community to create a culture of honesty, featuring a set of shared values and shared standards for judging transgressions against those values" (Pecorari and Shaw 2010).

\section{Originality checking and detecting plagiarism}

Ninety-three of the 100 HEIs that responded to a survey in 2007 (Tennant, Rowell, and Duggan 2007), reported 9,229 cases of plagiarism, equivalent to 7.2 cases per 1,000 students, with wide variation between institutions, from 3.1 to 13.7 cases per 1,000 students. Larger institutions reported proportionally more cases of plagiarism and stricter penalties.

It is difficult to make comparisons over time as few institutions have baseline data on plagiarism detection (Badge and Scott 2009). Culwin (2006a, 2006b) and other studies) has undertaken a number of studies considering the use of plagiarism detection tools in his own university. He found that the average percentage of nonoriginality detected in first year work over four years had increased from 17.2 to $28 \%$. This, he thought, was due to the improvement in plagiarism detection software and the availability of online materials for students to use. He also found a correlation between the amount of non-originality and the likelihood of non-completion of the first year.

\section{Background}

Canterbury Christ Church University's plagiarism policy takes an 'educate and support' rather than a punish stance, based on the principle of fairness in assessment, 


\section{Graham-Matheson and S. Starr}

for example by "designing out" plagiarism. At the time of the study, the use of Turnitin for originality checking was not compulsory and was undertaken in around 40 programmes in 17 of the 23 teaching departments across all five faculties, involving around 5,000 students. There was planned use for around 1,500 more students in at least a further 10 programmes, including a further three teaching departments. Turnitin submission statistics show a total of 26,271 originality reports produced with the majority - 19,563 - in the 12 months up to January 2011.

University procedures at the time of the study stated that where Turnitin was used it must be applied to all students taking an assignment, not to individual or small groups of students, students must be advised of its use in advance (no retrospective application) and students must have a formative experience of Turnitin before it is used summatively. Apart from this, how Turnitin was applied was at the discretion of programme leaders, e.g. whether students had access to their originality reports and the number of draft assignments they were permitted to submit.

Staff in programmes or departments using Turnitin were offered training by their Faculty Learning Technologist with online support available. Students received guidance from their tutors at the beginning of their programmes or when the first assignment was due, often both, with online support. Programme handbooks were included with information on the use of Turnitin (where applicable) and the plagiarism policy.

\section{Methodology}

The research was a case study of one university, with data collected via surveys and follow up interviews. All students and teaching staff were invited to take part in online surveys (using the Bristol Online Survey service) on their understanding, perceptions and experiences of Turnitin, plagiarism and University policy. Where possible the staff and student surveys had identical questions, to facilitate comparison. Three hundred and sixty-seven students and 62 staff responded, of whom $166(45 \%)$ and $39(63 \%)$ had used Turnitin for originality checking, respectively. A follow-up e-mail "interview" (using an extended questionnaire) was undertaken with 34 students who volunteered to take part, 21 of whom $(62 \%)$ had used Turnitin. Face-to-face, semi-structured interviews were held with 26 staff, of whom 15 were teaching staff and the others in various related academic and professional service roles. Qualitative analysis of the free text responses and interviews was undertaken, supported by quotations from the participants. The research was conducted within the University's ethical guidelines. Interviewees gave their written consent. Those who participated in the online survey and emails were fully informed about the project and taken to have given their consent by virtue of taking part. The students who participated in the study were spread across all faculties and all levels of study with the highest number (34.3\%) at Level $4 /$ first year undergraduates.

\section{Findings}

The following findings are from the online survey of staff and students and the email survey of some of the students, which explored the same issues in the online survey but in greater depth. 
Knowledge and understanding of Turnitin and plagiarism

\begin{tabular}{lrrrrr}
\hline & Students & \multicolumn{2}{c}{ Staff } \\
\hline Have you heard of Turnitin? & & & & \\
Yes & 266 & $72.5 \%$ & 61 & $98.4 \%$ \\
No & 101 & $27.5 \%$ & 1 & $1.6 \%$
\end{tabular}

Respondents were given the description of what Turnitin does in relation to originality

checking, and asked whether they knew this before:

\begin{tabular}{|c|c|c|c|c|}
\hline Knew all about Turnitin & 160 & $43.6 \%$ & 53 & $85.5 \%$ \\
\hline Have heard about Turnitin but didn't know much about it & 115 & $31.3 \%$ & 8 & $12.9 \%$ \\
\hline $\begin{array}{l}\text { Didn't know much about Turnitin } \\
\text { ave you heard of the University's plagiarism policy? }\end{array}$ & 92 & $25.1 \%$ & 1 & $1.6 \%$ \\
\hline Yes & 344 & $93.7 \%$ & 62 & $100 \%$ \\
\hline No & 23 & $6.3 \%$ & 0 & 0 \\
\hline ow well do you understand the plagiarism policy? & & & & \\
\hline Fully understand it & 186 & $52.4 \%$ & 26 & $41.9 \%$ \\
\hline Partly understand it & 157 & $44.2 \%$ & 34 & $54.8 \%$ \\
\hline Don't understand it all & 12 & $3.4 \%$ & 2 & $3.2 \%$ \\
\hline
\end{tabular}

Students were given an extract from the policy in relation to the University's approach to using

Turnitin and asked how aware they were of this?
Fully aware
$164 \quad 44.7 \% \quad 43$
$69.4 \%$
Partially aware
$134 \quad 36.5 \% \quad 16$
$25.8 \%$
Not aware at all
$69 \quad 18.8 \% \quad 3 \quad 4.8 \%$

Students were asked if they had been required to use Turnitin as part of their studies, staff

whether they had directed/overseen the use of Turnitin

$\begin{array}{lrrrr}\text { Yes } & 166 & 45.2 \% & 39 & 62.9 \% \\ \text { No } & 201 & 54.8 \% & 23 & 37.1 \% \\ \text { ow do you view your experience of using Turnitin? } & & & & \\ \text { Very positive } & 50 & 29.2 \% & 14 & 35.9 \% \\ \text { More positive than negative } & 66 & 38.6 \% & 19 & 48.7 \% \\ \text { Indifferent } & 47 & 27.5 \% & 5 & 12.8 \% \\ \text { More negative than positive } & 7 & 4.1 \% & 1 & 2.6 \% \\ \text { Very negative } & 1 & 0.6 \% & 0 & 0\end{array}$

If you do not currently use Turnitin, how willing would you be to use it in the future?

\begin{tabular}{lrrrc} 
Fully willing & 149 & $57.1 \%$ & 18 & $58.1 \%$ \\
Willing but with reservations & 75 & $28.7 \%$ & 10 & $32.3 \%$ \\
Indifferent & 28 & $10.7 \%$ & 1 & $3.2 \%$ \\
Not very willing & 4 & $1.5 \%$ & 0 & 0 \\
Not willing at all & 5 & $1.9 \%$ & 2 & $6.5 \%$ \\
\hline
\end{tabular}

Students who had used Turnitin clearly valued its use:

It allows me to check for plagiarism so that I know I haven't copied anyone's work. The draft facility enables you to double check that all information is appropriately referenced and not plagiarised.

This is a similar finding to the study by Rolfe (2011) where all the students who responded to a survey $(\mathrm{n}=52)$ had positive experiences of using Turnitin. In Ireland, Ledwith and Rasquez (2008) found that students thought their academic environment was fairer since the introduction of Turnitin: in this study a few students who were not using Turnitin thought it could be useful in terms of fairness:

If people are not willing to use it then they must be worried about plagiarism. I am not worried about this as I try my hardest to reference my work correctly. 


\section{Graham-Matheson and S. Starr}

Means the work we do is our work and will stop people cheating and gaining marks they don't deserve.

Cheating is wrong and the university should go to whatever lengths deemed necessary/ economically viable in order to oust offenders.

Plagiarism is allowing those who work hard to get levelled by people who put in little or no effort at all! Anything that promotes fair education and qualifications, I'm up for it!

Other comments revealed a lack of understanding, even fear, about how Turnitin might be used:

I am not sure whether it would be something to trust ...

I was told that it is used to detect plagiarism, not to avoid it, therefore I am afraid of how it works, how accurate it is, how difficult it will be to use.

I would be happy to but I would be worried that I might be accused of plagiarism even though I did not plagiarise.

Student concern about inadvertent plagiarism was also found by Dahl (2007).

Staff and students who had used Turnitin were asked how it had been used:

\begin{tabular}{|c|c|c|c|c|}
\hline & \multicolumn{2}{|c|}{ Students } & \multicolumn{2}{|c|}{ Staff } \\
\hline & $N=166$ & $\%$ & $N=39$ & $\%$ \\
\hline For originality checking of students' work & 128 & 77 & 35 & 90 \\
\hline For e-feedback on students' work & 26 & 16 & 8 & 20 \\
\hline For electronic submission of students' work only & 74 & 44 & 11 & 28 \\
\hline Turnitin was discussed with students in a lecture or seminar & 111 & 67 & 27 & 69 \\
\hline Tutors showed example originality reports relevant to the subject & 88 & 53 & 21 & 54 \\
\hline $\begin{array}{l}\text { Information about Turnitin was provided in the programme or } \\
\text { module handbook }\end{array}$ & 71 & 43 & 22 & 56 \\
\hline Students had a chance to submit a draft piece of work to Turnitin & 98 & 59 & 29 & 74 \\
\hline $\begin{array}{l}\text { Students were able to view their own originality report for draft } \\
\text { work }\end{array}$ & 89 & 54 & 25 & 64 \\
\hline $\begin{array}{l}\text { Students were able to view their own originality report for final } \\
\text { submissions }\end{array}$ & 54 & 32 & 18 & 46 \\
\hline
\end{tabular}

Staff were asked why they had used Turnitin with their students, and students were asked why they thought they had been required to use Turnitin:

\begin{tabular}{lrrrrrr}
\hline & \multicolumn{2}{c}{ Students } & & \multicolumn{2}{c}{ Staff } \\
\cline { 2 - 3 } \cline { 6 - 7 } & \multicolumn{2}{c}{$N=166$} & $\%$ & & $N=39$ & $\%$ \\
\hline To detect plagiarism & 144 & 89 & & 26 & 67 \\
To deter students from plagiarising & 98 & 59 & 28 & 72 \\
To help students understand how to avoid plagiarising & & 82 & 49 & 28 & 72 \\
To help students improve their academic writing skills & & 61 & 37 & & 22 & 56 \\
Other reasons & 6 & 4 & 3 & 8 \\
\hline
\end{tabular}

The other reasons given for using Turnitin were all around electronic submission of work, apart from one student who commented:

To make your life difficult 
It is not possible to make direct comparisons across programmes or subjects but it is clear from the above that staff and student views about why Turnitin has been used are roughly in-line.

The effect of Turnitin on detecting and dealing with plagiarism

Yes

No

Staff were asked whether they had any direct experience of Turnitin

$20 \quad 52.6 \% \quad 18 \quad 47.4 \%$ leading to an alleged case of plagiarism

Staff were asked what effect they thought Turnitin had had on plagiarism in the University (up to three responses allowed)

$\begin{array}{ll}\text { Increased detection by tutors of possible plagiarism } & 24\end{array}$

$\begin{array}{lr}\text { Decreased overall amount of plagiarism } & 15\end{array}$

Increase in actual numbers of plagiarism cases brought 9

$\begin{array}{ll}\text { No effect on overall amount of plagiarism } & 6\end{array}$

Decrease in actual numbers of plagiarism cases brought 4

No effect in actual numbers of plagiarism cases brought 4

No effect on detection by tutors of possible plagiarism $\quad 2$

$\begin{array}{ll}\text { Increased overall amount of plagiarism } & 0\end{array}$

Decreased detection by tutors of possible plagiarism $\quad 0$

To date, the University has not formally recorded the involvement of Turnitin in alleged cases of plagiarism but around half of the teaching staff involved in the research who had used Turnitin had direct experience of it leading to an alleged case of plagiarism. Teaching staff commented that Turnitin helps cut down on the work involved in detection (e.g. Googling) and provides documentary evidence for panels. It is seen as particularly useful in detecting collusion between students, although it cannot apportion blame, which can be frustrating. It was suggested that Turnitin is very helpful in alleged cases of plagiarism because it provides some "evidence" which is a basis for discussion with the student

... it has been useful in identifying substantial plagiarism in a piece of work. The student is denying they plagiarised so this provides clear evidence and a basis for the initial discussion with the student.

Helped to spot all the minor plagiarism in a report with large chunks of copied material. Better evidence. It's unlikely that the case would have been brought to my attention without Turnitin.

\section{Understanding the policy and rationale for using Turnitin}

The online survey shows that most students who have used Turnitin understand what it technically does and what the University's approach to using it is. Most were aware that the University's approach combines education with detection and punishment but they thought it was more about detection (79\%) and deterrence $(54 \%)$ than education to avoid plagiarism (45\%) and helping improve academic skills (33\%).

Around two-thirds of students interviewed describe the University's approach to plagiarism as being mainly about standards, definitions and rigour. They referred to 


\section{Graham-Matheson and S. Starr}

the University working to raise students' awareness and warning them about plagiarism more than actively helping them to avoid it. Other studies (Abasi and Graves 2008; Devlin 2006) have found that university policies on plagiarism contain little if any reference to an educative approach or to helping students improve their academic writing.

My understanding is that the University take a very strong stance when plagiarism is concerned, this can lead to movement through the disciplinary hierarchy, removal of work from submission and of the student from the programme.

I think it is really good that they take it very seriously; some of the talks we had are a bit scary, but students need that so that they don't just "copy and paste" articles and quotes.

Around a third described the approach as more educative.

It teaches me how to avoid it. It encourages me to read more and support my ideas with empirical evidence.

Staff tended to see the education message as stronger than that of detect and punish, whereas students saw the detect/punish message as the stronger one. Most staff interviewees $(69 \%)$ understood the University's increasingly educational approach to dealing with plagiarism and were supportive of this although a small number were not, feeling that the new approach is too lenient and allowing students who may have plagiarised resubmissions without penalty to be unfair to other students.

What's the point of detecting it when students who are found to have plagiarised still remain on the course?

Differing views from academics were also found by Crisp (2007), with some academics regarding plagiarism as an education and training issue and others seeing it related to "honesty and reputation" (p. 3).

The student survey shows a third of students who use Turnitin were able to see their originality report for final submissions but is unclear on their on-going ability to submit drafts. Over half $(62 \%)$ of students interviewed who use Turnitin reported on-going educational use, e.g. being able to submit draft assignments, representing almost half of the programmes covered. Almost half the students interviewed were able to view the originality report for their final submissions and almost a quarter were able to submit a draft for every assignment. At the time of the study, there was consideration/planning on several programmes for allowing draft submissions beyond the initial formative experience.

\section{Training and support}

From the online survey, most students who had used Turnitin (134) said their help and support had come from tutors, although there was also support from online tutorials and other students. Only half of the students surveyed who use Turnitin (84/166) said they had received help and advice about plagiarism, perhaps suggesting that some students do not fully understand what the Turnitin reports are showing them. Support for staff had come mainly from Faculty Learning Technologists and online tutorials. Tutors said they had given students advice about what plagiarism is (31), helped with referencing (35) and provided other help to improve academic writing (35). 
There was clear evidence from the academic staff interviews that those who use Turnitin want to ensure that students have full information about using Turnitin and avoid plagiarism through handbooks, lectures and seminars and discussion. There was a general feeling amongst staff that students received plenty of support, although they would always say that they needed more. It was clear that although a wide range of learning support is offered, not all students engage with this unless it is a compulsory part of their course. Rolfe (2011) suggests that both students and staff need more help in interpreting originality reports, so that they can use Turnitin in a "self-service" way and improve a wider range of academic skills.

\title{
Staff views
}

The academic staff interviewees who were using Turnitin in their programmes viewed the education of students about plagiarism and the use of Turnitin as very important, introducing it early in programmes as an important element of study skills. A few lecturers saw Turnitin as a tool that works in isolation, not something that they could use within and to support their teaching.

There was a feeling amongst staff that some international students, where quoting from an expert is seen as a mark of respect and an appropriate thing to do, have difficulty understanding the concept of plagiarism. Writing in Australia McCarthy and Rogerson (2009) also found that other nationalities can have a different perspective regarding the sharing of work, a view supported by Hayes and Introna (2005):

\begin{abstract}
many overseas students, on arriving at UK universities, are more familiar with a "textbook based" teaching approach than one that requires them to consult a number of sources. In Asian, Chinese, and Greek universities, lectures often systematically cover the material in the textbook, and the exam requires students to demonstrate that they can recall all relevant material from one textbook and their lecture notes - often verbatim. Often there is minimal or no interpretation or commentary expected from the student. (p. 225)
\end{abstract}

Others thought this might just be an excuse, and several staff commented in the interviews that the only cases of plagiarism they had dealt with were from Home students. Of the nine EU/International students interviewed, six perceived Turnitin to be advantageous, both for helping them to avoid plagiarism and for catching "cheats". None voiced any perceived disadvantages.

I cannot say there is the importance in this case whether we are from EU or from UK, because it helps everyone. However, it was something new for me and I can see it an advantage, because in my country there is no such programme for plagiarism ...

In the interviews, a small number of staff felt that some students deliberately referred to more obscure journals or conference papers that are not part of the Turnitin database to avoid detection

Sometimes I fear that it may encourage a "cleverer" type of plagiarism for those students who want to cheat and realise that all they need to do is find more obscure textbooks that are not online.

Staff valued Turnitin in enabling them to detect plagiarism more quickly but a small number commented on the amount of effort needed to set up Turnitin and to 


\section{Graham-Matheson and S. Starr}

monitor/read originality reports as being a waste of time. Software detection tools appear to provide an objective measure of plagiarism but in practice they offer evidence that must be subject to academic interpretation and judgement, so the way they are implemented plays a key role in their effectiveness (Badge and Scott 2009). A number of studies have shown that academics have welcomed the time saved by using electronic detection to investigate individual plagiarism cases but as the most widely used tools only display matching text, there has been an increase in the time they need to spend checking plagiarism reports in order to apply academic judgement (Mulcahy and Goodacre 2004; Sutherland-Smith and Carr 2005) or to help students with writing skills (Maloney and O'Kane 2007) as well as needing training in order to be able to interpret the reports.

It is very useful in confirming suspicions or the reverse, although of course it can't show whether the "plagiarism" was intentional or not, that can be followed up by the lecturer. Turnitin is an obvious time-saver for markers and discourages plagiarism simply by being there.

Some staff who were interviewed commented on the need for greater consistency in the use of Turnitin across the University. This includes whether Turnitin is used or not as well as how it is used, e.g. allowing drafts, seeing originality reports for final submissions. Most agreed with the increasingly formative approach.

\section{The role of Turnitin in reducing plagiarism}

It is not possible to measure the direct impact of Turnitin in avoiding plagiarism. Although there is an increased number of reported cases of plagiarism across the University, this could be due to a number of reasons, including increasing student numbers, greater efforts to detect plagiarism or more weaknesses in students' writing skills.

Over half of students interviewed who use Turnitin say it has helped them avoid plagiarism with just under half reporting that it has helped improve their referencing and just over a quarter that it has improved their writing generally. All of the students who regard themselves as less confident about avoiding plagiarism reported that Turnitin helped them, compared with two-fifths of the students who regard themselves as more confident. Perhaps surprisingly, there was no correlation between the on-going formative use of Turnitin and students reporting that it had helped them to avoid plagiarism. Students on programmes that only have an initial formative experience were as likely to report that Turnitin had helped them avoid plagiarism as those on programmes which provide on-going opportunities to submit drafts or access to originality reports. Various studies, including Ledwith and Rasquez (2008) and Barrett and Malcolm (2006) have shown that there is a dramatic drop in the amount of non-originality detected in second drafts, although the fact that these studies have generally been conducted only with a single module or class led Badge and Scott (2009) to question issues around longer term effectiveness.

A quarter of students surveyed who use Turnitin, and who commented on the survey, referred to the value of Turnitin in helping them to avoid plagiarism

It was helpful to see if there were any issues with my work that I needed to rephrase, reference or delete.

... at first it made me panic but now I understand that it is a great tool to improve your academic writing. 
Over half of the staff surveyed who use Turnitin thought it had directly contributed to reduced plagiarism, improved referencing and better writing. One lecturer asks all new undergraduate students to bring in a marked A level essay from their recent school days and runs them through Turnitin - students are said to be shocked at the amount of non-original material in their work.

\section{Conclusion}

The results of the study suggest that Turnitin is seen as a useful tool by students and may help up to half of students to avoid plagiarising, particularly the less confident students.

There was a general understanding of the University's reasons for using Turnitin and staff as a basis for helping students to avoid plagiarism valued it. The originality reports were seen to be very useful in discussions with students, particularly those having problems understanding plagiarism and academic writing requirements. Although the research was set up to assess the extent of the formative use of Turnitin, not its impact, it was clear, particularly from the interviews with academic staff, that Turnitin is a valuable tool in teaching students to understand, and avoid, plagiarism.

Perhaps the most surprising finding was that there was no correlation between the on-going formative use of Turnitin and students reporting that it had helped them to avoid plagiarism. Students on programmes that only have an initial formative experience were as likely to report that Turnitin had helped them avoid plagiarism as those on programmes which provide on-going opportunities to submit drafts or access to originality reports. This perhaps suggests that with initial training and support, followed by the opportunity to submit an assignment through Turnitin and receive formative feedback, students feel confident that they understand how to write their assignments with accurate referencing. As the study did not set out to look at the difference in impact between initial and on-going formative use of Turnitin, further research is needed.

There was a strong feeling from students involved in the study that they would like Turnitin to be available more widely, and this is in accord with the University's policy of equity for students. The report of this study for the Senior Management Team recommended that the use of Turnitin should be rolled out across the University, accompanied by more information and training for both students and staff. This was accepted, and from September 2011 the use of Turnitin for originality checking was made compulsory for all assignments for which it is suitable.

\section{References}

Abasi, A. R. \& Graves, B. (2008) 'Academic literacy and plagiarism: conversations with international graduate students and disciplinary professors', Journal of English for Academic Purposes, vol. 7, no. 4, pp. 221-233.

Ashworth, P., Bannister, P. \& Thorne, P. (1997) 'Guilty in whose eyes? University students' perceptions of cheating and plagiarism in academic work and assessment', Studies in Higher Education, vol. 22, no. 2, pp. 187-203.

Badge, J. \& Scott, J. (2009) 'Dealing with plagiarism in the digital age', [online] Available at: http://evidencenet.pbworks.com/Dealing-with-plagiarism-in-the-digital-age

Barrett, D. (2011) 'The epidemic at Britain's universities', The Daily Telegraph, 5 March, [online] Available at: http://www.telegraph.co.uk/education/educationnews/8363345/Thecheating-epidemic-at-Britains-universities.html 


\section{Graham-Matheson and S. Starr}

Barrett, R. \& Malcolm, J. (2006) 'Embedding plagiarism education in the assessment process', International Journal for Educational Integrity, vol. 2, no. 1, pp. 38-45.

Barrie, J. (2008) 'Emerging educational practices for more original writing', Paper presented at the Third International Plagiarism Conference, Gateshead.

Blackboard. (2008) 'Blackboard's SafeAssign (TM) used for one million student papers', [online] Available at: http://reuters.com/article/pressRelease/idUS127286 + 19-May-2008 + MW20080519

Carroll, J. (2007) A Handbook for Deterring Plagiarism in Higher Education, 2nd edn, Oxford Centre for Learning and Staff Development, Oxford.

Crisp, G. T. (2007) 'Staff attitudes to dealing with plagiarism: issues and perspectives from one Australian university', International Journal for Educational Integrity, vol. 3, no. 1, pp. $3-15$.

Culwin, F. (2006a) 'An active introduction to academic misconduct and the measured demographics of misconduct', Assessment and Evaluation in Higher Education, vol. 31, no. 2 , pp. $167-182$.

Culwin, F. (2006b) 'I think my students are less naughty, but maybe the tools are more effective', Second International Plagiarism Conference, Gateshead, [online] Available at: http://www.plagiarismadvice.org/research-papers/category/2009

Dahl, S. (2007) 'Turnitin: the student perspective on using plagiarism detection software', Active Learning in Higher Education, vol. 8, no. 2, pp. 173-191.

Davis, M. \& Carroll, J. (2009) 'Formative feedback within plagiarism education: is there a role for text-matching software'? International Journal for Educational Integrity, vol. 5, no. 2, pp. 58-70, [online] Available at: www.ojs.unisa.edu.au/index.php/IJEI/article/view/614

de Jager, K. \& Brown, C. (2010) 'The tangled web: investigating academics' views of plagiarism at the University of Cape Town', Studies in Higher Education, vol. 35, no. 5, pp. 513-528.

Devlin, M. (2006) 'Policy, preparation and prevention: proactive minimisation of student plagiarism', Journal of Higher Education Policy and Management, vol. 28, no. 1, pp. 45-58.

Eckel, E. J. (2010) 'A reflection on Plagiarism, Patchwriting and the Engineering Master's Thesis', Issues and Science and Technology Librarianship, [online] Available at: http:// www.istl.org/10-summer/viewpoint.html

Flynn, S. (2010) 'Using Turnitin with large classes to support student writing', Paper presented to the Fourth International Plagiarism Conference, June 2010, [online] Available at: http:// www.plagiarismadvice.org/documents/conference2010/papers/4IPC_0016_final.pdf

Hayes, N. \& Introna, L. (2005) 'Cultural values, plagiarism, and fairness: when plagiarism gets in the way of learning', Ethics and Behavior, vol. 15, no. 3, pp. 213-231.

Howard, R. M. (1999) Standing in the Shadow of Giants: Plagiarists, Authors, Collaborators, Ablex, Stamford, CT.

iParadigms. (2012) 'Turnitin celebrates 20 million graded papers in Grademark', [online] Available at: http://www.iparadigms.com/news

Larkham, P. J. \& Manns, S. (2002) 'Plagiarism and its treatment in higher education', Journal of Further and Higher Education, vol. 26, no. 4, pp. 341-349.

Ledwith, A. \& Rasquez, A. (2008) 'Using anti-plagiarism software to promote academic honesty in the context of peer reviewed assignments', Studies in Higher Education, vol. 33, no. 4 , pp. $371-384$.

Mainka, C., Raeburn, S. \& Earl, S. (2006) 'A UK institution's university-wide approach to plagiarism: first results and recommendations', International Journal for Educational Integrity, vol. 2, no. 1, pp. 13-25.

Maloney, M. \& O'Kane, C. (2007) Using Turnitin in a large class, unpublished, cited in Flynn Martin, I., Stubbs, M. \& Troop, H. (2006) 'Weapons of mouse destruction: a 3D strategy for combating cut-and-paste plagiarism using the JISC plagiarism advisory service', Paper presented at the 2nd International Plagiarism Conference, Gateshead, [online] Available at: http://www.plagiarismadvice.org/media/2006papers/IanMartin.pdf

McCarthy, G. \& Rogerson, A. (2009) 'Links are not enough: using originality reports to improve academic standards, compliance and learning outcomes among postgraduate students', International Journal for Educational Integrity, vol. 5, no. 2, pp. 47-57.

McGowan, U. (2005) 'Educational integrity: a strategic approach to anti-plagiarism', 2nd AsiaPacific Educational Integrity Conference, University of Newcastle, Australia http:// www.newcastle.edu.au/conference/apeic/papers_pdf/mcgowan_0548_edd.pdf 
Mulcahy, S. \& Goodacre, C. (2004) 'Opening Pandora's box of academic integrity: using plagiarism detection software', in Beyond the Comfort Zone: Proceedings of the 21st ASCILITE Conference, eds R. Atkinson, C. McBeath, D. Jonas-Dwyer, \& R. Phillips, Perth, Australia: ASCILITE. pp. 688-696.

Pecorari, D. (2003) 'Good and original: plagiarism and patchwriting in academic secondlanguage writing', Journal of Second Language Writing, vol. 12, no. 4, pp. 317-345.

Pecorari, D. \& Shaw, M. (2010) 'University teachers discussing plagiarism: divided perspectives on teaching writing and shaping a culture of honesty', Paper presented at the 4th Plagiarism Conference, 4-6 June 2010, Northumbria University, [online] Available at: http://www.plagiarismadvice.org/conference/previous-plagiarism-conferences/4th-plagiarismconference-2010

Rolfe, V. (2011) 'Can Turnitin be used to provide instant formative feedback?', British Journal of Educational Technology, vol. 42, no. 4, pp. 701-710.

Sutherland-Smith, W. \& Carr, R. (2005) 'Turnitin.com: teachers perspectives of anti-plagiarism software in raising issues of educational integrity', Journal of University Teaching and Learning Practice, vol. 2, no. 3, [online] Available at: http://ro.uow.edu.au/jutlp/vol2/ iss $3 / 10 /$

Tennant, P., Rowell, G. \& Duggan, F. (2007) Academic Misconduct Benchmarking Research Project: Part 1: The range and spread of penalties available for student plagiarism among UK Higher Education Institutions, Higher Education Academy, York, [online] Available at: http://www.jiscpas.ac.uk/AMBeR/index

Wiggins, C. (2010) 'Turning points: building a framework for active student engagement and learning with Turnitin', Paper presented to the Fourth International Plagiarism Conference, Northumbria University, [online] Available at: http://www.plagiarismadvice. org/conference/previous-plagiarism-conferences/4th-plagiarism-conference-2010

Woessner, M. (2004) 'Beating the house: how inadequate penalties for cheating make plagiarism an excellent gamble', PS: Political Science and Politics, vol. 37, no. 2, pp. 313-320. 